\title{
Effect of Magnetic Nanoparticles Functionalized with Doxorubicin in Breast Cancer Cells
}

Elisa Parcero Hernandes ${ }^{1}$, Raquel Dosciatti Bini ${ }^{2}$, Karina Midori Endo ${ }^{1}$, Danielle Lazarin-Bidóia ${ }^{3}$, Veronica Elisa Pimenta Vicentini ${ }^{1}$ and Luiz Fernando Cótica ${ }^{2}$

1. Biotecnology, Genetics and Cell Biology Department, State University of Maringá, Maringá, PR, Brasil. ${ }^{2}$ Physics Department, State University of Maringá, Maringá, PR, Brasil. 3. Pharmaceutical Sciences Department, State University of Maringá, Maringá, PR, Brasil.

Magnetic nanoparticles (MNP) have been of great interest in a wide range of applications due to their unique physicochemical characteristics [1]. MNP can be conjugated with various bioactive ligands and can be used for in vitro and in vivo treatment of tumors [2]. Therefore, the objective of this work was to evaluate the cytotoxic activity and morphological changes in breast cancer cells (MCF-7) exposed to magnetite MNP functionalized with doxorubicin (NPMag+Dox) and silica coated magnetite functionalized with doxorubicin (NPMag+Si+Dox) by the MTT assay and SEM. For the MTT assay, cells were treated with different concentrations of Dox, NPMag+Dox and NPMag+Si+Dox for 24 and $48 \mathrm{~h}$. For the SEM, cells treated with NPMag+Dox and NPMag+Si+Dox for $24 \mathrm{~h}$ were fixed, dehydrated, critical point-dried in $\mathrm{CO}_{2}$, sputter-coated with gold and observed using a FEI Quanta 250. The MTT assay showed that cells treated with NPMag+Dox and NPMag+Si+Dox present decrease in viability after 24 and $48 \mathrm{~h}$ when compared with untreated cells. The SEM showed the untreated cells firmly attached to the substrate, exhibiting abundance of short microvilli arranged throughout the cell surface. Regarding the cells incubated with NPMag+Dox and NPMag+Si+Dox, SEM showed that most cells had extensions of their body, presenting morphology similar with the untreated control. The dimensions as outer membrane surface structure, adhesion and general shapes do not appear to have been altered by treatment with the nanoparticles. However, cells treated only with Dox showed damage in the plasma membrane and loss of microvilli. Nonetheless other studies should be conducted to demonstrate the effects of these magnetic nanoparticles on tumor cells.

References:

[1] S. Behrens, Curr. Opin. Biotechnol. 39 (2016), p. 89.

[2] J. Chomoucka et al., Pharmacol. Res. 62 (2010), p. 144.

[3] This research was supported by CNPq (Brazil).
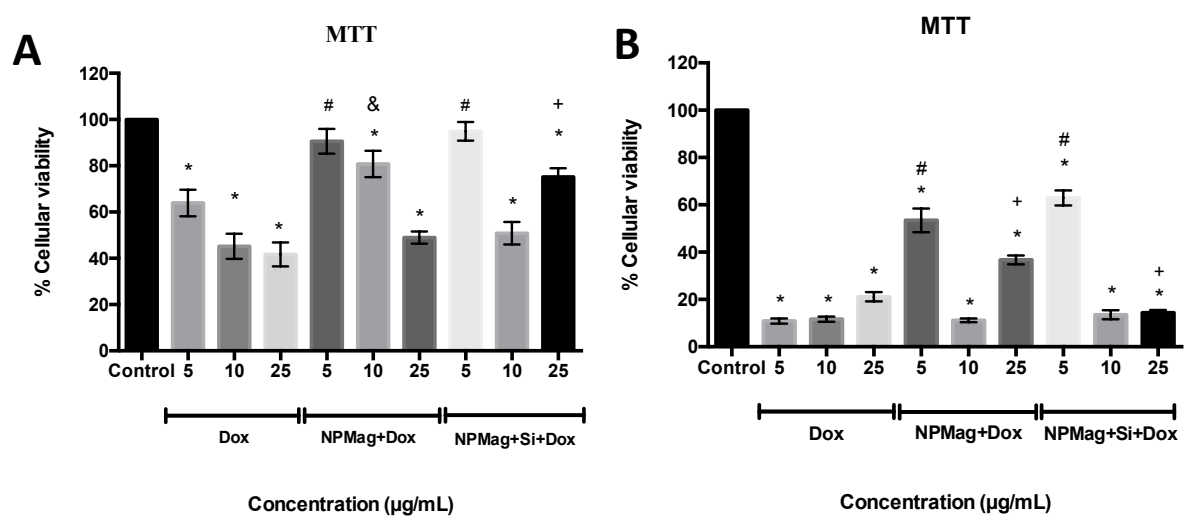

Figure 1 - Mean and standard deviation obtained by the MTT test. Control groups (DMEM $+10 \%$ FBS), and different concentrations of NPMag+Doxo and NPMag+Si+Doxo (5, 10 and $25 \mu \mathrm{g} / \mathrm{ml})$ were incubated with MCF-7 cells for 24 hours (A) and 48 hours (B). Data are expressed as percentage of the untreated control.* Statistically significant difference in relation to control $(\mathrm{p}<0.05)$. \# Statistically significant difference in relation to Doxorubicin $5 \mu \mathrm{g} / \mathrm{ml}(\mathrm{p}<0.05)$. \& Statistically 
significant differences in relation to Doxorubicin $10 \mu \mathrm{g} / \mathrm{ml}(\mathrm{p}<0.05)$. + Statistically significant differences in relation to Doxorubicin $25 \mu \mathrm{g} / \mathrm{ml}(\mathrm{p}<0.05)$.
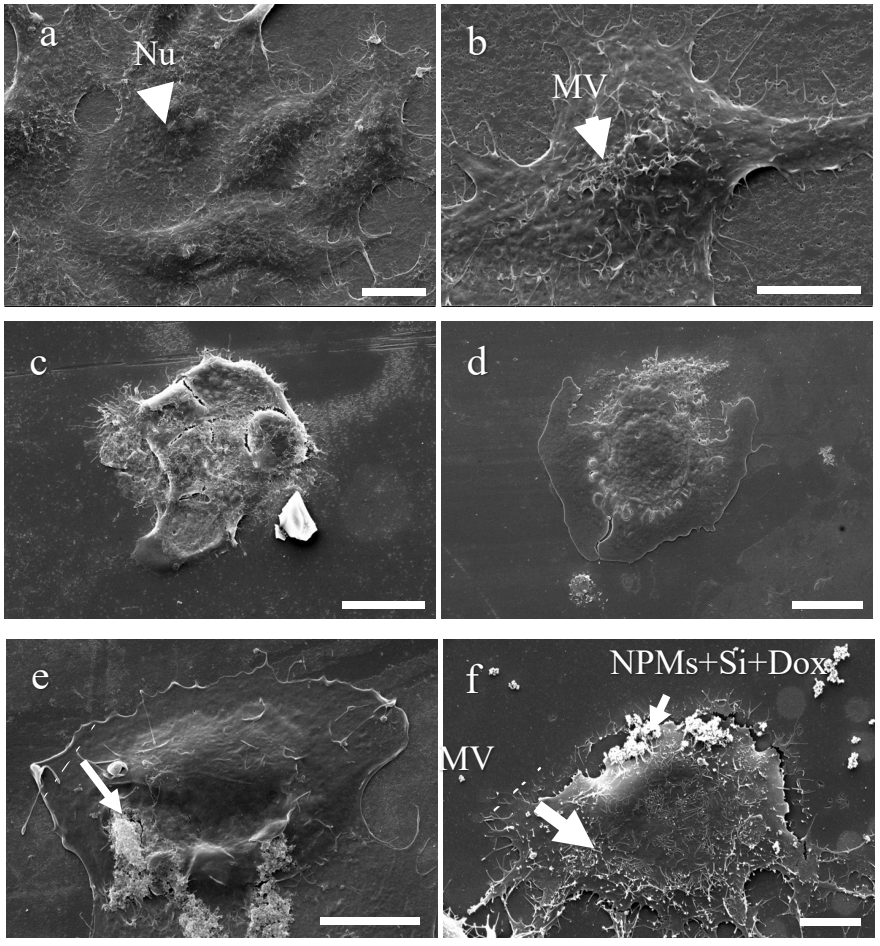

Figure 2 - Scanning electron microscopy (SEM) images of MCF-7 cells, incubated with different magnetic nanoparticle treatments for 24 hours. (a, b) Control, Bar: $15 \mu \mathrm{m}, 10 \mu \mathrm{m}$, respectively; (c, d)

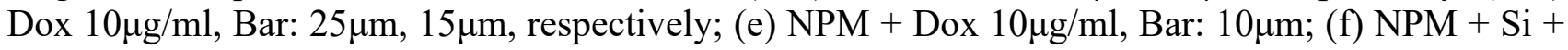
Dox 10 $\mathrm{g} / \mathrm{ml}$ Bar: $10 \mu \mathrm{m}$. Microvilli (MV); Nucleolus (Nu). 